\title{
Hubungan Kelekatan Ayah dan Kontrol Diri dengan Kesejahteraan Subjektif serta Kesejahteraan Psikologis sebagai Mediator pada Mahasiswa
}

\author{
Muhammad Novvaliant Filsuf Tasaufi, Syarifah Naimi Anisa, Nafisah Rahmi, Audith \\ Jasmine Sabrina Isliko \\ Program Studi Psikologi, Fakultas Psikologi dan Ilmu Sosial Budaya, Universitas Islam Indonesia, \\ Yogyakarta
}

\begin{abstract}
Abstrak. Kelekatan ayah dapat membantu mahasiswa dalam mengatasi berbagai macam persoalan. Penelitian ini bertujuan untuk melihat dinamika psikologis mahasiswa tersebut dengan berfokus pada hubungan antara kelekatan ayah dengan kontrol diri di mana kesejahteraan subjektif (SWB) dan kesejahteraan psikologis (PWB) menjadi mediator pada mahasiswa di Yogyakarta. Subjek penelitian ini adalah mahasiswa S1 yang berdomisili di Yogyakarta $(\mathrm{N}=$ 245). Penelitian ini menggunakan lima skala, dua skala untuk variabel kes ejahteraan subjektif, satu skala untuk variabel kesejahteraan psikologis, satu skala untuk variabel kontrol diri dan satu skala untuk variabel keterikatan ayah. Skala yang digunakan antara lain: (a) Safisfaction with Life Scale yang dibuat oleh Diener et al (1985); (b) Positive and Negative Affect Scales oleh Watson et al (1988); (c) Ryff's Psychological Well-Being Scale yang dikembangkan oleh C. D Ryff (1989); (d) Skala Kontrol Diri dari Tangney et al (2004); dan (e) Skala kelekatan ayah yang dikembangkan oleh Armsden dan Greenberg (1987). Data kemudian dianalisis dengan menggunakan teknik mediation analysis melalui aplikasi Jeffreys's Amazing Statistics Program (JASP). Hasil penelitian menunjukkan bahwa kelekatan ayah tidak memiliki efek secara langsung pada kontrol diri, namun kesejahteraan subjektif dan kesejahteraan psikologis dapat berperan sebagai mediator hubungan antara kelekatan ayah dan kontrol diri.
\end{abstract}

Kata Kunci: kelekatan pada ayah, kesejahteraan psikologis, kesejahteraan subjektif, kontrol diri, mediator, mahasiswa

\section{Relationship between Father's Attachment and Self-Control with Subjective Well- being and Psychological Well-being as Mediator for Undergraduate Students}

Abstract. Father attachment can help undergraduate students in overcoming various kinds of problems. This study aims to examine the dynamics of these undergraduate students that focus on the relationship between fatherhood attachment and self-control in which subjective wellbeing (SWB) and psychological well-being (PWB) mediate among students in Yogyakarta. The subjects of this study were undergraduate students who lived in Yogyakarta $(\mathrm{N}=245)$. This study uses five scales, two scales for the subjective well-being variable, one for the psychological well-being variable, one for the self-control variable and one for the fatherhood attachment variable. The scales used include (a) Satisfaction with Life Scale created by Diener et al (1985); (b) Positive and Negative Affect Scales by Watson et al (1988); (c) Ryff's Psychological WellBeing Scale developed by Ryff (1989); (d) Self-Control Scale from Tangney et al (2004); and (e) The fatherhood attachment scale developed by Armsden and Greenberg (1987). The data were then analyzed using mediation analysis techniques through the JASP application. The results showed that fatherhood attachment did not have a direct effect on self-control, but subjective well-being and psychological well-being could act as mediators of the relationship between fatherhood attachment and self-control.

Keywords: fatherhood attachment, self-control, subjective well-being, psychological well-being, mediator, undergraduate student

Korespondensi: Muhammad Novvaliant Filsuf Tasaufi. Email: novvaliant@uii.ac.id 
Kehidupan mahasiswa S1 memiliki tantangan tersendiri mengingat mahasiswa S1 yang berada dalam fase transisi dari remaja akhir menuju dewasa awal. Mahasiswa beralih dari masa remaja menuju ke dewasa awal dan berupaya mengembangkan kemandirian dengan melepaskan sikap kekanak-kanakan dan bergantung pada orangtua serta mempersiapkan kehidupan masa depan setelah lulus dari perguruan tinggi (Cullaty, 2011). Tantangan yang harus dihadapi oleh mahasiswa S1 antara lain banyaknya permasalahan akademis maupun non akademis yang dihadapi sehingga mempengaruhi kesehatan fisik maupun psikisnya. Contoh permasalahan akademis yang perlu dihadapi oleh mahasiswa disampaikan oleh Kholidah dan Alsa (2012) yang menyebutkan bahwa beberapa masalah yang menimbulkan stres atau tekanan pada mahasiswa adalah adanya persaingan dalam berprestasi, tuntutan IPK yang tinggi, banyaknya tugas perkuliahan, ujian evaluasi belajar, merasa salah dalam memilih jurusan kuliah, mendapat ancaman droup out, gangguan hubungan interpersonal, konflik dengan lingkungan, manajemen waktu, manajemen diri, dan manajemen keuangan yang kurang baik. Sementara dari sisi non akademis, Leopoldina et al (2017) memberikan gambaran permasalahan yang dihadapi mahasiswa seperti masalah dalam hubungan sosial, kecemasan akan perpisahan, dan tidak tinggal bersama orangtua, yang kemudian mempengaruhi kemampuan akademiknya.
Banyaknya permasalahan yang mesti dihadapi baik itu dari sisi akademis maupun non akademis, membuat mahasiswa menjadi rentan dengan munculnya berbagai macam gangguan psikologis. Salah satu penelitian dari Qonitatin et al (2011) menemukan bahwa $26 \%$ dari subjek penelitiannya yang merupakan mahasiswa, mengalami gangguan depresi ringan, 20,24\% mengalami depresi yang sudah mengarah ke klinis, 8,33 \% mengalami depresi sedang, 1,19 \% mengalami depresi berat, dan sisanya normal. Hal tersebut menunjukkan bahwa sejumlah 55,95 \% (47/84 orang) subjek penelitian Qonitatin et al (2011) mengalami depresi. Salah satu manifestasi dari depresi adalah adanya pikiran untuk bunuh diri atau menyakiti diri sendiri. Pikiran untuk melakukan tindakan bunuh diri hingga realisasi bunuh diri berhubungan dengan tingkat keputusasaan dan kualitas hidup yang memprediksikan tingkat depresi mahasiswa (Farabaugh et al., 2012). Berbagai kasus bunuh diri dan tindakan kekerasan yang dilakukan oleh seorang mahasiswa menggambarkan adanya gejala stres, mulai dari stres ringan hingga tingkat berat. Hal tersebut disebabkan oleh rasa khawatir yang berlebihan dan terlalu banyaknya pikiran negatif (Kholidah \& Alsa, 2012).

Berbagai macam gangguan psikologis ini berdampak pada kemampuan individu dalam mengontrol diri sehingga rentan melakukan halhal yang justru membahayakan diri sendiri. Menurut Tangney et al (2004) kontrol diri 
merupakan kemampuan untuk mengesampingkan atau mengubah respon batin seseorang, serta mencegah kecenderungan perilaku yang tidak diinginkan dan menahan diri dari melakukan perilaku tersebut. Banyak dari orang yang mengalami depresi muncul perilaku yang tidak diinginkan yang dimulai dengan munculnya lintasan pikiran untuk bunuh diri atau menyakiti diri sendiri dengan tujuan untuk mengakhiri atau mengurangi masalah dan rasa kesengsaraan yang dirasakan. Selain itu, temuan dari Senduk (2016) yang menyebutkan bahwa terdapat mahasiswa yang tergoda untuk mencari hiburan dan menghilangkan rasa lelah atas kesibukan dalam mengerjakan tugas pokok sebagai seorang mahasiswa dengan mengunjungi diskotik. Situasi dalam diskotik memperbesar peluang munculnya perilaku negatif lain sehingga mahasiswa tidak mampu menahan diri dari mengkonsumsi NAPZA, merokok, mabuk, hingga seks bebas sebagai manifestasi kemampuannya dalam kontrol diri yang maladaptif. Gambaran ini menunjukkan bahwa tuntutan untuk belajar bukanlah hal yang ringan, serta belajar berhubungan erat dengan aktifitas jiwa, seperti afeksi dan kontrol diri mahasiswa (Rahmi, 2013).

Kontrol diri menjadi penting karena dapat membantu mahasiswa terutama dalam menghadapi permasalahan psikologis atau perilaku yang muncul akibat tekanan akademis maupun non akademis yang harus dihadapi oleh mahasiswa. Tangney et al (2004) menjelaskan bahwa kontrol diri secara garis besar melibatkan suatu kemampuan untuk berubah dan beradaptasi yang baik antara diri sendiri dan dunia, kontrol diri juga bermain peran penting dalam aspek lain dari penyesuaian psikologis, seperti: kecemasan, depresi, perilaku obsesif-kompulsif, dan keluhan somatik. Kemampuan dalam mengembangkan kemampuan kontrol diri diharapkan dapat membuat seseorang menjadi pribadi yang matang, yang bisa menerima diri sendiri, dan diterima di lingkungan masyarakat luas.

Keluarga memiliki peranan yang sangat penting dalam pembentukan kontrol diri seseorang, mengingat penanaman dan perkembangan nilai-nilai moral anak terbentuk pertama kali di lingkungan keluarga. Nilai-nilai yang tertanam dalam keluarga, akan dibawa oleh anak pada kehidupan selanjutnya termasuk saat menapaki usia remaja akhir atau dewasa awal, dimana mayoritas mahasiswa S1 berada dalam rentang usia ini. Abdullah (2014) menyebutkan bahwa pengasuhan oleh ayah akan memberikan warna tersendiri pada pembentukan karakter anak. Pada ayah, anak belajar ketegasan, sifat maskulin, kebijaksanaan, ketrampilan kinestetik, dan kemampuan kognitif. Ayah akan membantu anak untuk bersikap tegar, kompetitif, menyukai tantangan dan senang bereksplorasi. Bahkan penelitian dari Ramadhanti et al (2021) yang menyimpulkan bahwa kelekatan ayah memiliki hubungan yang signifikan dengan taraf kecerdasan emosional seorang anak yang 
membantu anak untuk mampu mengenali emosi diri sendiri, mampu mengelola emosi, mampu memotivasi diri, mampu berempati dan mampu membina hubungan dengan orang lain.

Dari sudut pandang yang lain, dukungan keluarga memiliki peranan yang penting dalam mengembangkan kesejahteraan subjektif individu. Penelitian oleh Brannan et al (2013) terhadap mahasiswa di Iran, Yordania, dan Inggris menemukan bahwa dukungan dari keluarga secara signifikan dapat memprediksikan setiap aspek-aspek kesejahteraan subjektif (kepuasan hidup, positive affect dan negative affect) di masingmasing negara, sedangkan dukungan dari teman-teman tidak dapat memprediksikan kesejahteraan subjektif seperti dukungan keluarga.

Mahasiswa yang memiliki kesejahteraan subjektif yang tinggi merupakan mahasiswa yang sangat puas akan hidupnya, dan lebih sering merasakan afeksi positif dibandingkan dengan afeksi negatif (Ed Diener et al., 2015). Mahasiswa yang memiliki kepuasan dalam hidup, menurut Diener \& Seligman (2002) hampir tidak akan pernah berpikiran untuk bunuh diri, dapat mengingat peristiwa positif, dan lebih sering merasakan bahagia pada setiap harinya. Dengan demikian, mahasiswa dengan perasaan bahagia dan puas atas hidupnya akan lebih mudah untuk mengontrol dirinya sehingga menjadi lebih resisten terhadap munculnya gangguan psikologis.
Sementara itu, Maharani (2017) mengungkapkan dalam penelitiannya bahwa terdapat hubungan antara kelekatan pada orangtua dengan kesejahteraan psikologis. Lebih spesifik lagi, Adamsons \& Johnson (2013) menyebutkan bahwa kelekatan aman dengan ayah berhubungan dengan kesejahteraan individu, sementara ketidakhadiran ayah dalam pengasuhan anak dapat meningkatkan faktor risiko di sepanjang rentang kehidupan anak (Dickerson, 2011) serta berhubungan dengan harga diri dan kepuasan hidup anak (Allgood et al., 2012). Utami (2015) juga memperkuat bahwa terdapat hubungan yang positif antara keterlibatan ayah dengan kesejahteraan psikologis pada mahasiswi.

Sementara itu, Hurlock (1980) menyebutkan bahwa salah satu faktor dari kontrol diri adalah faktor internal berupa usia di mana seiring bertambahnya usia dari seseorang, maka semakin baik perkembangan imajinasi, pengertian, kemampuan mengingat dan mengantisipasi yang dapat mempengaruhi terjadinya reaksi-reaksi emosional sehingga kemampuan mengontrol diri seseorang semakin membaik. Di sisi lain, individu dengan kesejahteraan psikologis yang baik akan memiliki penyesuaian diri yang baik seperti dapat menilai diri maupun situasi secara realistik, menerima keadaan, dan mengontrol diri sehingga tidak akan merasa tertekan dengan segala kondisi yang dialaminya (Wulandari, 2016). 
Dengan demikian sosok ayah memiliki peranan yang penting dalam kehidupan anak. Peran sosok ayah di antaranya memberikan lingkungan yang kondusif, menjadi panutan, mendukung keberhasilan anak (Fathi, 2011), menjadi pemimpin yang memiliki tanggung jawab atas keluarga, memiliki tugas untuk mencari nafkah, mendidik, mengajari ilmu agama, mengasuh (R. Novianti, 2018), memberikan dukungan ekonomi, dan melatih kedisiplinan (Papalia \& Fieldman, 2014).

Sikap dan tingkah laku seorang anak tidak terlepas dari pengaruh dan pendidikan orang tua (Taufik et al., 2013). Penelitian Taufik et al (2013) mengatakan bahwa tingkah laku yang tidak dikehendaki pada diri anak dapat merupakan gambaran dari keadaan dalam keluarga. Penelitian mengenai hubungan kelekatan ayah secara langsung pada kontrol diri belum banyak dilakukan meskipun beberapa penelitian menunjukkan ke arah sana Penelitian-penelitian tersebut menunjukkan bahwa kehangatan, dukungan, dan keteraturan dari ayah melalui pola pengasuhan dan proses pembentukan karakter dapat membantu anak untuk bersikap tegar, kompetitif, menyukai tantangan dan senang bereksplorasi (Abdullah, 2014), mempengaruhi kecerdasan emosional (Ramadhanti et al., 2021), membantu anak untuk memiliki penyesuaian sosial yang lebih baik (Basuki \& Indrawati, 2017), serta dapat membantu mahasiswa untuk mengembangkan identitas menjadi dewasa, mampu membuat keputusan karir dan pekerjaan, memiliki kemampuan untuk mengelola berbagai tekanan yang dirasakan (Mattanah et al., 2011), dan menghadapi berbagai tantangan dalam hidupnya (Anwar \& Anwar, 2017). Sementara itu, Dumont \& Paquette (2013) kelekatan dengan ayah berpengaruh terhadap kemampuan anak dalam meregulasi emosi diri. Stimulasi dan kedisiplinan yang diberikan oleh ayah sebagai figur lekat akan memengaruhi perkembangan anak dalam perasaan aman dan kepercayaan diri.

Dari berdasarkan hasil penelitianpenelitian sebelumnya peneliti tertarik untuk mengeksplorasi lebih lanjut sejauh mana peran mediator kesejahteraan subjektif dan kesejahteraan psikologis bagi hubungan antara kelekatan ayah dan kontrol diri pada mahasiswa. Adapun hipotesis yang diajukan dalam penelitian ini adalah terdapat hubungan positif antara kelekatan ayah dengan kontrol diri melalui mediator kesejahteraan subjektif dan kesejahteraan psikologis pada mahasiswa. Rumusan hipotesis tersebut menjadi dasar model konseptual yang digambarkan sebagai berikut : 


\section{Gambar 1}

\section{Kerangka Konsep}

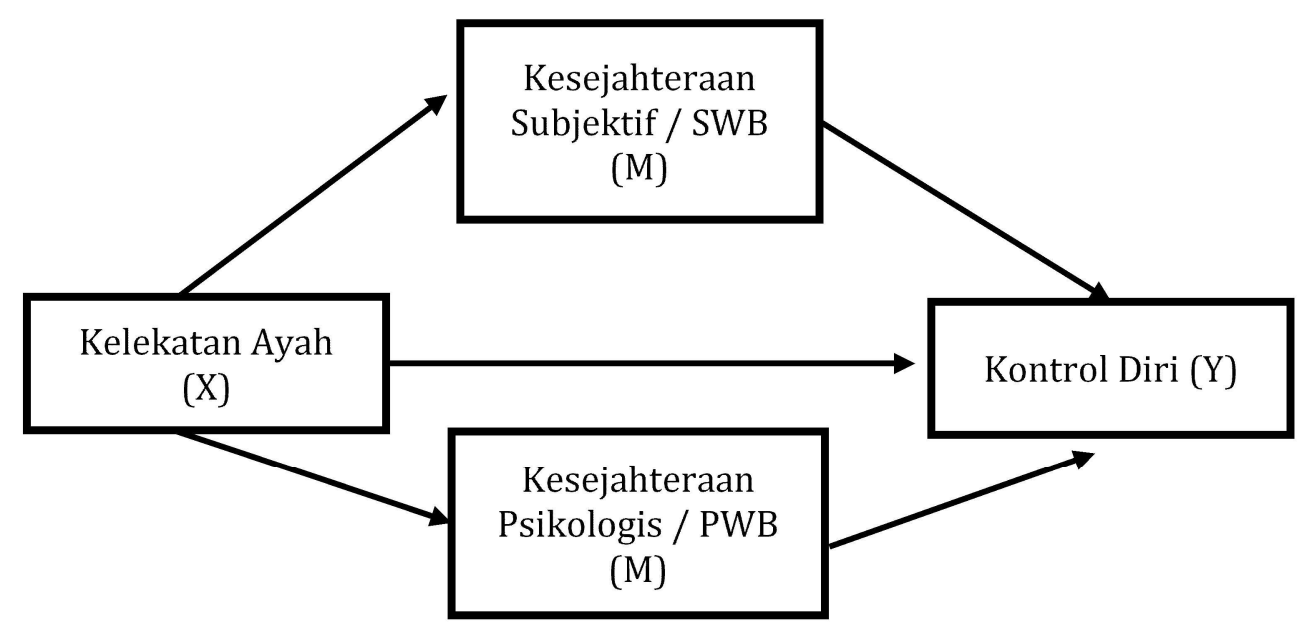

\section{Metode}

\section{Desain penelitian}

Penelitian ini menggunakan pendekatan quantitative correlation research yang bertujuan untuk melihat hubungan kausal antar variabel-variabel penelitian, yaitu mengenai ada tidaknya hubungan kelekatan ayah terhadap kontrol diri melalui mediator kesejahteraan subjektif (SWB) dan kesejahteraan psikologis (PWB) pada mahasiswa.

\section{Subjek penelitian}

Subjek yang terlibat dalam penelitian ini adalah mahasiswa S1 yang berusia dalam rentang 18-25 tahun, di mana rentang usia tersebut merupakan rentang usia yang merupakan peralihan antara remaja akhir menuju dewasa awal. Pemilihan subjek dalam penelitian ini menggunakan teknik pengambilan sampel non random purposive sampling, yaitu pemilihan sampel sesuai dengan yang dikehendaki dengan pertimbanganpertimbangan tertentu. Sementara subjek yang dilibatkan dalam penelitian ini berjumlah total 245 orang yang terdiri dari 60 laki-laki dan 185 perempuan.

\section{Metode pengumpulan data}

Penelitian ini menggunakan beberapa skala penelitian yang telah melalui beberapa tahapan adaptasi. Peneliti menerjemahkan dalam bahasa Indonesia dengan menyesuaikan konteks bahasa dan budaya, dengan tujuan memastikan tidak ada perubahan makna pada butir-butir yang diadaptasi. Berikut ini skala yang digunakan dalam penelitian ini

\section{Kontrol diri}

Kontrol diri diukur dengan mengacu pada skala Self-Scoring Self-Control Scale yang disusun oleh Tangney et al (2004). Skala kontrol diri ini terdiri dari 10 butir dengan aspek Breaking Habits (Mengontrol diri), Resiting 
Temptation (Menahan Godaan) dan SelfDiscipline (Disiplin Diri) individu dalam menyelesaikan masalah. Skala ini terdiri dari 4 pilihan jawaban, yakni sangat tidak sesuai, tidak sesuai, sesuai dan sangat sesuai. Skor ini bergerak dari 1 hingga 4 pada setiap butir. Peneliti melakukan uji coba pada responden ( $\mathrm{N}$ =245) dan ditemukan 2 buir yang memiliki nilai kurang dari .25, yakni butir no 4 dan no 6 . Setelah butir digugurkan, skala kontrol diri memiliki besaran Alpha Cronbach sebesar .712.

\section{Kelekatan ayah}

Kelekatan dengan ayah diukur dengan skala Inventory Parent and Peer Attachment (IPPA) yang dikembangkan oleh Armsden \& Greenberg (1987) berdasarkan teori kelekatan dari Bowlby. Skala ini terdiri atas 3 subskala, yaitu skala kelekatan dengan ibu, skala kelekatan dengan ayah, dan skala kelekatan dengan teman sebaya. Penelitian ini hanya menggunakan 1 subskala, yaitu skala kelekatan dengan ayah karena hanya mengukur kelekatan mahasiswa dengan ayah. Peneliti menggunakan skala kelekatan ayah dari IPPA yang digunakan dalam penelitian (Felani \& Goretti, 2017). Skala kelekatan ayah terdiri dari 25 butir dengan aspek kepercayaan, komunikasi dan keterasingan. Skala ini terdiri dari 4 pilihan jawaban, yakni sangat tidak sesuai, tidak sesuai, sesuai dan sangat sesuai. Skala ini diujicoba pada responden $(\mathrm{N}=245)$ dan ditemukan 1 butir yang gugur yakni butir nomer 14 karena memiliki nilai kurang dari .25. Setelah digugurkan, skala kelekatan ayah memiliki skor Alpha Cronbach sebesar .940.

\section{Kesejahteraan subjektif (SWB)}

Penilaian tingkat kesejahteraan subjektif mengacu pada skoring yang berlaku di Satisfaction with Life Scale (SWLS) yang disusun oleh Diener et al (1985) dan Positive Affect \& Negative Affect Scale (PANAS) yang disusun oleh Watson et al (1988). SWLS terdiri dari 4 pilihan jawaban, yakni sangat tidak setuju, tidak setuju, setuju dan sangat setuju sementara PANAS juga terdiri dari 4 pilihan jawaban, yakni tidak pernah, jarang, sering dan selalu. Skor ini bergerak dari 1 hingga 4 pada setiap butir. Pada SWLS peneliti melakukan uji coba pada responden $(\mathrm{N}=245)$ dan tidak ditemukan ada butir yang gugur (yang bernilai kurang dari .25) dengan perolehan Alpha Cronbach sebesar .782. Sedangkan pada PANAS juga dilakukan uji coba pada responden $(\mathrm{N}=$ 245) dan ditemukan butir yang gugur (butir nomor 12) sehingga diperoleh Alpha Cronbach sebesar .801 untuk afek positif dan .825 untuk afek negatif.

\section{Kesejahteraan Psikologis (PWB)}

Skala kesejahteraan psikologis diadaptasi dari The Scale of Psychological Well-being (SPWB) yang dikembangkan oleh Ryff (1989) dan telah diadaptasi menjadi berbahasa Indonesia. Skala ini terdiri dari 6 pilihan jawaban, yakni sangat tidak sesuai, tidak sesuai, agak tidak sesuai, agak sesuai, sesuai dan sangat sesuai. Skor ini bergerak dari 1 hingga 6 pada 
setiap butir. Peneliti melakukan uji coba pada responden $(\mathrm{N}=245)$ dan ditemukan 3 butir yang memiliki nilai kurang dari .25, yakni butir nomer 2, 6 dan 8. Setelah butir digugurkan, skala kontrol diri memiliki besaran Alpha Cronbach sebesar.786.

\section{Metode analisis data}

Penelitian ini menggunakan mediation analysis melalui perangkat lunak JASP. Analisis tersebut dilakukan untuk menguji pengaruh langsung atau tidak langsung antara variabel tergantung dan variabel bebas.

\section{Hasil}

Penelitian ini bertujuan untuk melihat hubungan antara kelekatan ayah dengan kontrol diri melalui kesejahteraan subjektif dan kesejahteraan psikologis sebagai mediator pada mahasiswa S1. Penelitian ini melibatkan 245 responden yang dideskripsikan sebagai berikut:

\section{Tabel 1}

Data Demografis Responden

\begin{tabular}{lcc}
\hline \multicolumn{1}{c}{ Karakteristik } & $n$ & $\%$ \\
\hline Jenis Kelamin & 185 & 75.51 \\
$\quad$ Perempuan & 60 & 24.49 \\
Laki-laki & & \\
& & \\
Komunikasi & 207 & 84.49 \\
$\quad 3$ kali seminggu & 38 & 15.51 \\
$>3$ kali seminggu & & \\
& & \\
Tempat Tinggal & 194 & 79.18 \\
$\quad$ Kos/Kontrakan/Asrama & 51 & 20.82 \\
\hline Rumah
\end{tabular}

Catatan. $N=245$

\section{Tabel 2}

Kategorisasi Responden Penelitian

\begin{tabular}{lcccccccc}
\hline \multirow{2}{*}{ Kategorisasi } & \multicolumn{2}{c}{$\begin{array}{c}\text { Kontrol } \\
\text { Diri }\end{array}$} & \multicolumn{2}{c}{$\begin{array}{c}\text { Kelekatan } \\
\text { Ayah }\end{array}$} & \multicolumn{2}{c}{ SWB } & \multicolumn{2}{c}{ PWB } \\
& $n$ & $\%$ & $n$ & $\%$ & $n$ & $\%$ & $n$ & $\%$ \\
\cline { 2 - 10 } Sangat Rendah & 42 & 17.1 & 44 & 17.96 & 44 & 17.96 & 9 & 3.7 \\
Rendah & 45 & 18.8 & 61 & 24.89 & 44 & 17.96 & 58 & 23.7 \\
Sedang & 50 & 20.4 & 42 & 17.14 & 56 & 22.86 & 115 & 46.9 \\
Tinggi & 49 & 20.0 & 57 & 23.26 & 45 & 18.36 & 58 & 23.7 \\
Sangat Tinggi & 59 & 24.4 & 41 & 16.75 & 56 & 22.86 & 5 & 2 \\
\hline
\end{tabular}

Catatan. $N=245$ 
Deskripsi data penelitian digunakan untuk mengetahui keadaan sampel pada tiap variabel penelitian, terdiri atas $\min , \max$, mean, standar deviasi dan kategorisasi. Penelitian ini menemukan bahwa responden memiliki kontrol diri yang tidak jauh berbeda di masingmasing kategori. Namun responden yang paling banyak memiliki kontrol diri yang sangat tinggi sebesar $24.4 \%$ dan yang paling sedikit memiliki kontrol diri yang sangat rendah yakni sebesar 17.1\%. Begitupun dengan variabel kelekatan ayah, secara umum masing-masing kategori tidak jauh berbeda dimana jumlah terbanyak responden memiliki kelekatan ayah dengan kategori rendah sebesar 24.89\%. Sementara responden yang memiliki kelekatan ayah sangat tinggi hanya berjumlah $16.75 \%$. Pada variabel kesejahteraan subjektif, jumlah masing-masing kategori tidak banyak berbeda dengan rentang $17.96 \%$ - 22.86\%. Sementara pada variabel kesejahteraan psikologis mayoritas (lebih dari $50 \%$ ) berada pada kategori sedang.

\section{Uji normalitas}

Peneliti juga melakukan uji asumsi normalitas untuk mengetahui distribusi dari sebaran data penelitian. Berdasarkan hasil uji normalitas dapat diketahui bahwa keseluruhan variabel berdistribusi normal.

\section{Tabel 3}

Hasil Uji Normalitas

\begin{tabular}{lcc}
\hline \multicolumn{1}{c}{ Variabel } & K-S & $p$ \\
\hline Kontrol Diri & .052 & $.200^{*}$ \\
Kelekatan Ayah & .057 & $.096^{*}$ \\
Kesejahteraan Subjektif & .043 & $.200^{*}$ \\
Kesejahteraan Psikologis & .035 & $.200^{*}$ \\
\hline
\end{tabular}

Catatan. K-S = Kolmogorov-Smirnov; ${ }^{*} p>.05$

Setelah melakukan uji normalitas, peneliti menggunakan metode analisis mediasi. Adapun hasil dari analisis mediasi adalah sebagai berikut:

\section{Tabel 4}

Hasil Analisis Mekanisme Mediator

\begin{tabular}{lc}
\hline & $p$ \\
\hline Efek Langsung & .063 \\
$\quad$ Kelekatan Ayah $\rightarrow$ Kontrol Diri & \\
Efek Tidak Langsung & \\
$\quad$ Kelekatan Ayah $\rightarrow$ SWB $\rightarrow$ Kontrol Diri & .146 \\
$\quad$ Kelekatan Ayah $\rightarrow$ PWB $\rightarrow$ Kontrol Diri & $.001^{*}$ \\
Efek Total & \\
$\quad$ Kelekatan Ayah $\rightarrow$ Kontrol Diri & $.01^{*}$ \\
\hline Catatan. ${ }^{*} p<.05$ &
\end{tabular}




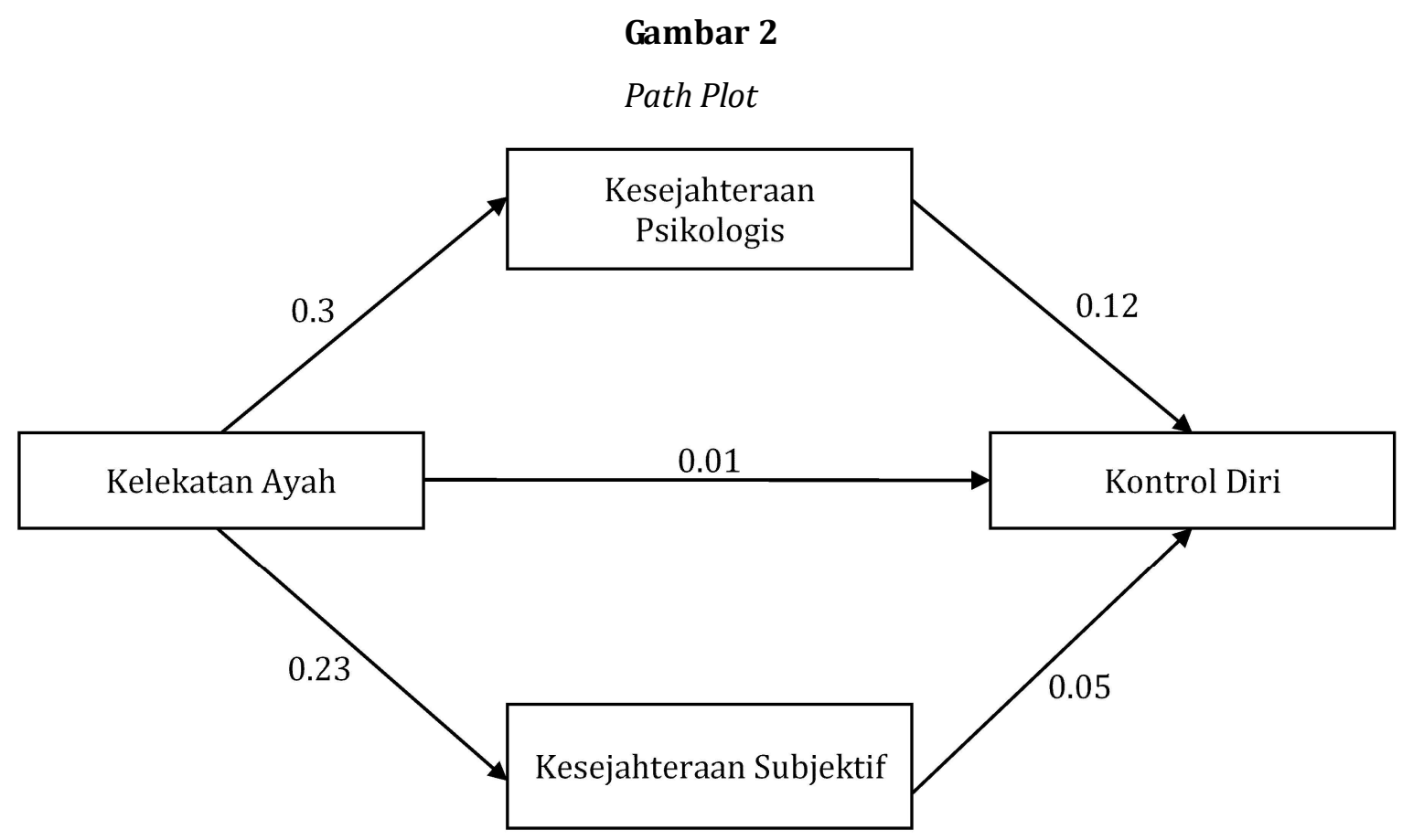

Berdasarkan hasil analisis, rincian pada tabel 4 menjelaskan bahwa tidak terjadi efek secara langsung dari kelekatan ayah terhadap kontrol diri. Selain itu, kesejahteraan subjektif ditemukan tidak menjadi mediator secara signifikan dalam hubungan antara kelekatan ayah dengan kontrol diri. Akan tetapi, kesejahteraan psikologis dapat memediasi secara penuh hubungan antara kelekatan ayah dengan kontrol diri. Saat dilakukan analisis secara bersamaan, kesejahteraan subjektif dan kesejahteraan psikologis dapat memediasi secara penuh hubungan kelekatan ayah dengan kontrol diri. Hasil penelitian menunjukkan hipotesis penelitian ini diterima.

\section{Pembahasan}

Jika dilakukan analisis secara terpisah, kesejahteraan psikologis dapat memediasi hubungan kelekatan ayah terhadap kontrol diri lebih besar daripada variable kesejahteraan subjektif. Dalam beberapa literatur, kelekatan ayah berhubungan dengan kesejahteraan psikologis pada remaja (Masso, 2018) dan mahasiswi (Utami, 2015). Sementara kesejahteraan psikologis memiliki korelasi dengan kontrol diri (Sibuea, 2019) dimana kesejahteraan psikologis memiliki sumbangan yang cukup besar terhadap kontrol diri, yakni sebesar $11.4 \%$. Psychological well-being atau kesejahteraan psikologis merupakan suatu pencapaian penuh dari potensi psikologis dan suatu kondisi individu yang dapat menerima kekuatan dan kelemahan diri, memiliki tujuan hidup, mengembangkan relasi yang positif dengan orang lain, memiliki pribadi mandiri, mampu mengendalikan lingkungan, dan perkembangan pribadi (Ryff, 1989; Ryff \& Keyes, 1995). Karakteristik orang yang memiliki kesejahteraan psikologis merujuk 
pada pandangan tentang orang yang berfungsi penuh (fully-functioning person), pandangan Maslow tentang aktualisasi diri (self actualization), pandangan Jung, Baynes, \& Beebe tentang individuasi, konsep Allport tentang kematangan, juga sesuai dengan konsep Erikson dalam menggambarkan individu yang menggapai integrasi dibanding putus asa (Lopez \& Snyder, 2003). Sementara itu, kesejahteraan psikologis memiliki beberapa dimensi antara lain otonomi, penerimaan diri, hubungan positif dengan orang lain, penguasaan lingkungan, tujuan hidup serta adanya pertumbuhan pribadi (Ryff \& Keyes, 1995).

Kesejahteraan psikologis dapat memediasi hubungan antara kelekatan ayah dengan kontrol diri karena terdapat dimensi dalam kesejahteraan psikologis yang berkaitan erat dengan kontrol diri, yakni pertumbuhan pribadi di mana seseorang akan mengembangkan potensi yang perlu dilakukan untuk tumbuh dan berkembang sebagai manusia. Setiap orang diharapkan untuk terus berkembang daripada memilih berada pada keadaan yang konstan. Pertumbuhan pribadi yang berkelanjutan dan realisasi diri sangat mendukung terhadap meningkatnya kesejahteraan psikologis seseorang (Ryff, 1989). Selain itu, penguasaan lingkungan yang berarti kemampuan seseorang dalam memilih atau menciptakan lingkungan yang sesuai dengan kondisi psikisnya. Juga dikatakan sebagai kemampuan seseorang untuk mengubah lingkungan secara kreatif melalui aktivitas fisik atau mental seseorang (Ryff, 1989). Kemampuan ini dapat dimanifestasikan dengan bagaimana individu menyesuaikan diri dengan berbagai tekanan yang dihadapi seperti tekanan akademis maupun non akademis sehingga terhindar dari berbagai macam gangguan psikologis. Di sisi lain, salah satu faktor yang membentuk kesejahteraan psikologis adalah dukungan sosial, dimana dukungan dari keluarga terutama orangtua dapat meningkatkan psychological well being seseorang (Ryff \& Keyes, 1995).

Peneliti menemukan bahwa kesejahteraan subjektif dan kesejahteraan psikologis dapat memediasi secara penuh hubungan antara kelekatan ayah dan kontrol diri. Selain itu, saat dilakukan analisis secara terpisah, kesejahteraan psikologis dapat memediasi hubungan kelekatan ayah terhadap kontrol diri, sedangkan kesejahteraan subjektif tidak memiliki kontribusi yang signifikan dalam memediasi hubungan antara kelekatan ayah dan kontrol diri. Hasil penelitian menunjukkan hipotesis penelitian ini diterima.

Psychological well-being atau kesejahteraan psikologis merupakan suatu pencapaian penuh dari potensi psikologis dan suatu kondisi individu yang dapat menerima kekuatan dan kelemahan diri, memiliki tujuan hidup, mengembangkan relasi yang positif dengan orang lain, memiliki pribadi mandiri, mampu mengendalikan lingkungan, dan perkembangan pribadi (Ryff, 1989; Ryff \& 
Keyes, 1995). Karakteristik orang yang memiliki kesejahteraan psikologis merujuk pada pandangan Rogers tentang orang yang berfungsi penuh (fully-functioning person), pandangan Maslow tentang aktualisasi diri (self actualization), pandangan Jung, Baynes, dan Beebe tentang individuasi, konsep Allport tentang kematangan, juga sesuai dengan konsep Erikson dalam menggambarkan individu yang menggapai integrasi dibanding putus asa (Lopez \& Snyder, 2003). Sementara itu, kesejahteraan psikologis memiliki beberapa dimensi antara lain otonomi, penerimaan diri, hubungan positif dengan orang lain, penguasaan lingkungan, tujuan hidup serta adanya pertumbuhan pribadi (Ryff \& Keyes, 1995).

Kesejahteraan psikologis dapat memediasi hubungan antara kelekatan ayah dengan kontrol diri karena terdapat dimensi dalam kesejahteraan psikologis yang berkaitan erat dengan kontrol diri, yakni penguasaan lingkungan yang berarti kemampuan seseorang dalam memilih atau menciptakan lingkungan yang sesuai dengan kondisi psikisnya. Juga dikatakan sebagai kemampuan seseorang untuk mengubah lingkungan secara kreatif melalui aktivitas fisik atau mental seseorang (Ryff, 1989). Kemampuan ini dapat dimanifestasikan dengan bagaimana individu menyesuaikan diri dengan berbagai tekanan yang dihadapi seperti tekanan akademis maupun non akademis sehingga terhindar dari berbagai macam gangguan psikologis. Di sisi lain, salah satu faktor yang membentuk kesejahteraan psikologis adalah dukungan sosial, dimana dukungan dari keluarga terutama orangtua dapat meningkatkan psychological well being seseorang (Ryff \& Keyes, 1995).

Hubungan antara kelekatan ayah dengan kepuasan hidup juga ditemukan pada penelitian (Allgood et al., 2012). Ayah yang memberikan kehangatan, dukungan, dan keteraturan menurut Novianti \& Alfiasari (2017) akan lebih merasakan kepuasan hidup. Hubungan antara kelekatan ayah dan afeksi individu ditemukan dalam penelitian yang dilakukan oleh Armsden \& Greenberg (1987) bahwa kelekatan ayah berpengaruh pada afek negatif seperti depresi, cemas, terisolasi, dan rasa bersalah individu. Selain itu, penelitian yang dilakukan oleh Fajarini \& Khaerani (2014) menyebutkan bahwa 11.7\% kelekatan aman memberikan sumbangan efektif terhadap kematangan emosi individu.

Kelekatan ayah terbentuk atas beberapa aspek dari kehidupan individu. Pada penelitian Armsden \& Greenberg (1987) menyebutkan bahwa kepercayaan, komunikasi, dan keterasingan menjadi aspek-aspek dari kelekatan antara individu dan ayah. Aspek kepercayaan mengacu pada kepercayaan yang diberikan individu pada ayah, dengan harapan bahwa ayah akan memahami dan memberikan respon pada kebutuhan dan keinginan individu. Dukungan sosial dari orangtua akan berdampak pada bagaimana individu mampu menyesuaikan diri di perkuliahan (Pratitis \& Wijaya, 2012). Munculnya perasaan positif 
akibat adanya dukungan dari ayah tersebut secara langsung berpengaruh pada kesejahteraan subjektif individu, karena tingginya perasaan positif merupakan bagian dari tingginya kesejahteraan subjektif.

Sementara kesejahteraan subjektif secara khusus tidak begitu memberikan efek mediasi yang signifikan pada kontrol diri. Penelitian Diener et al (2015) menyebutkan bahwa kesejahteraan subjektif merupakan evaluasi secara kognitif dan afektif terkait sejauh mana kehidupan yang dijalani telah mencapai seperti kehidupan yang diinginkan. Sementara Tangney et al (2004) mengatakan bahwa kontrol diri adalah kemampuan untuk mengesampingkan atau mengubah respons batin seseorang, serta mencegah kecenderungan perilaku yang tidak diinginkan dan menahan diri dari melakukan perilaku tersebut. Terdapat perbedaan sudut pandang antara kesejahteraan subjektif yang merupakan evaluasi dari sebuah kondisi, sementara kontrol diri merupakan kemampuan untuk menyesuaikan dengan kondisi tertentu sehingga hubungan di antara kedua variabel ini menjadi kurang relevan. Namun jika kesejahteraan subjektif digabungkan bersama dengan kesejahteraan psikologis, maka kesejahteraan subjektif dan kesejahteraan psikologis dapat memediasi secara penuh hubungan antara kelekatan ayah dan kontrol diri. Kesejahteraan sendiri merupakan kondisi dalam diri manusia yang sifatnya internal di mana Hurlock (1980) menyebutkan bahwa faktor internal yang termanifestasi dalam perkembangan imajinasi, pengertian, kemampuan mengingat dan mengantisipasi dapat mempengaruhi terjadinya reaksi-reaksi emosional sehingga kemampuan mengontrol diri seseorang semakin membaik.

\section{Simpulan}

Penelitian ini bertujuan untuk melihat hubungan antara kelekatan ayah dengan kontrol diri melalui kesejahteraan subjektif dan kesejahteraan psikologis sebagai mediator. Peneliti menyimpulkan bahwa hipotesis penelitian diterima, dimana saat dilakukan secara bersamaan, kesejahteraan subjektif dan kesejahteraan psikologis dapat memediasi hubungan antara kelekatan ayah dengan kontrol diri. Diharapkan penelitian ini dapat menjadi sumbangan khazanah keilmuan yang memiliki fokus pada bidang psikologi keluarga terutama terkait dengan dinamika pengasuhan oleh figur ayah, mengingat mayoritas penduduk Indonesia menganut paham matrilinear di mana figur ayah kurang banyak terlibat dalam pengasuhan, Hal tersebut ditegaskan oleh hasil penelitian ini yang menunjukkan bahwa keterlibatan ayah dalam mengasuh anak memiliki dampak jangka panjang bagi kehidupan anak.

\section{Saran}

Penelitian ini menggunakan perspektif teori perkembangan sosial emosional anak dalam mengevaluasi kelekatan mahasiswa pada ayahnya. Perspektif teori perkembangan sosial 
emosional remaja dan dewasa akan menjadi lebih relevan untuk memahami kelekatan mahasiswa pada ayah. Demikian pula penelitian selanjutnya bisa memperluas keterlibatan responden yang berperan sebagai ayah agar mendapatkan pemahaman yang lebih menyeluruh terkait dengan dinamika seputar kelekatan ayah. Eksplorasi mengenai kelekatan pada ibu dapat juga menjadi pertimbangan agar mendapat gambaran yang lebih luas terkait dengan pengasuhan orangtua.

\section{Pendanaan}

Penelitian ini didanai oleh Jurusan Psikologi, Fakultas Psikologi dan Ilmu Sosial Budaya Universitas Islam Indonesia.

\section{Referensi}

Abdullah, S. . (2014). Keterlibatan ayah dalam pengasuhan anak (Paternal involvement): Sebuah tinjauan teoritis. Universitas Mercu Buana/ : Yogyakarta.

Adamsons, K., \& Johnson, S. K. (2013). An updated and expanded meta-analysis of nonresident fathering and child wellbeing. Journal of Family Psychology, 27(4), 589-599. https://doi.org/ $10.1037 / \mathrm{a} 0033786$

Allgood, S. M., Beckert, T. E., \& Peterson, C. (2012). The role of father involvement in the perceived psychological wellbeing of young adult daughters: A retrospective study. North American Journal of Psychology, 14(1), 95-110.

Anwar, S. S., \& Anwar, S. (2017). Pertama kepada akhir: Perjalanan kehidupan manusia perspektif islam. Indragiri TM.

Armsden, G. C., \& Greenberg, M. T. (1987). The inventory of parent and peer attachment: Individual differences and their relationship to psychological well-being in adolescence. Journal of Youth and Adolescence, 16(5), 427-454. https:// doi.org/10.1007/BF02202939

B, H. E. (1980). Psikologi perkembangan suatu pendekatan sepanjang rentang kehidupan ((Edisi, 5)). Erlangga.

Basuki, N. W., \& Indrawati, E. S. (2017). Hubungan antara persepsi terhadap keterlibatan ayah dalam pengasuhan dan penyesuaian sosial pada mahasiswa fakultas teknik angkatan 2015 Universitas Diponegoro. Empati, 6(1), 312-316.

Brannan, D., Biswas-Diener, R., Mohr, C. D., Mortazavi, S., \& Stein, N. (2013). Friends and family: A cross-cultural investigation of social support and subjective wellbeing among college students. The Journal of Positive Psychology, 8(1), 65-75. h t tp s: / / doi.org / 10.1080 / 17439760.2012.743573

Cullaty, B. (2011). The role of parental involvement in the autonomy development of traditional-age college students. Journal of College Student Development, 52(4), 425-439. https:// doi.org/10.1353/csd.2011.0048

Dickerson, W. (2011). The positive effects of fathering and the negative effects of a father's absence in the lives of children from infancy to early adulthood: A review of the literature. Intuition, 7, 39-44.

Diener, E, \& Seligman, M. E. (2002). Very happy people. Psychological Science, 13(1), 8184.

Diener, Ed, Emmons, R. A., Larsen, R. J., \& Griffin, S. (1985). The satisfaction with life scale. Journal of Personality Assessment, 49(1), 71-75. https://doi.org/10.1207/ s15327752jpa4901_13

Diener, Ed, Oishi, S., \& Lucas, R. E. (2015). National accounts of subjective wellbeing. American Psychologist, 70(3), 234-242. https://doi.org/10.1037/ a0038899 
Dumont, C., \& Paquette, D. (2013). What about the child's tie to the father? A new insight into fathering, father-child attachment, children's socio-emotional development and the activation relationship theory. Early Child Development and Care, 183(3-4), 430-446. https://doi.org/ 10.1080/03004430.2012.711592

Fajarini, F., \& Khaerani, N. M. (2014). Kelekatan aman, religiusitas, dan kematangan emosi pada remaja. Jurnal Psikologi Integratif, 2(1), 22-29.

Farabaugh, A., Bitran, S., Nyer, M., Holt, D. J., Pedrelli, P., Shyu, I., Hollon, S. D., Zisook, S., Baer, L., Busse, W., Petersen, T. J., Pender, M., Tucker, D. D., \& Fava, M. (2012). Depression and suicidal ideation in college students. Psychopathology, 45(4), 228-234. https://doi.org/ $10.1159 / 000331598$

Fathi, B. (2011). Mendidik anak dengan Al Quran sejak janin. In Grasindo.

Felani, H. Y., \& Goretti, M. (2017). Hubungan kelekatan ayah dengan empati pada perilaku indirect aggression. Universitas Gadjah Mada/ : Yogyakarta.

Kholidah, E. N., \& Alsa, A. (2012). Berpikir positif untuk menurunkan stres psikologis. Jurnal Psikologi, 39(1), 67-75.

Leopoldina, Acatech, \& Akademienunion. (2017). Social media and digital science communication: Analysis and recommendations for dealing with chances and risks in a democracy.

Lopez, S. J., \& Snyder, C. R. R. (2003). Positive psychological assessment: A handbook of models and measures. In Database. https://doi.org/10.1037/10612-000

Lopez, S., \& Snyder, C. (2003). Positive psychological assessment: A handbook of models and measures. (S. J. Lopez \& C. R. Snyder (eds.)). American Psychological Association. https://doi.org/10.1037/ 10612-000

Maharani, R. (2017). Hubungan antara kelekatan pada orangtua dengan kesejahteraan psikologis remaja. Universitas Muhammadiyah Malang.

Masso, A. (2018). Pengaruh keterlibatan ayah dalam pengasuhan terhadap kesejahteraan psikologis remaja. Universitas Muhammadiyah Malang/ : Malang.

Mattanah, J. F., Lopez, F. G., \& Govern, J. M. (2011). The contributions of parental attachment bonds to college student development and adjustment: A metaanalytic review. Journal of Counseling Psychology, 58(4), 565-596. https:// doi.org/10.1037/a0024635

Novianti, D. S., \& Alfiasari, A. (2017). Kepuasan hidup mahasiswa tingkat pertama: Kaitannya dengan karakter mahasiswa dan gaya pengasuhan orang tua. Jurnal Ilmu Keluarga Dan Konsumen, 10(1), 1323. https://doi.org/10.24156/ jikk.2017.10.1.13

Novianti, R. (2018). Parent-ink: Stiletto book. Stiletto Book.

Papalia, E. D., \& Fieldman, R. T. (2014). Menyelami perkembangan manusia; Experience Human Developmen. Salemba Humanika.

Pratitis, N. ., \& Wijaya, I. . (2012). Efikasi diri akademik, dukungan sosial orangtua dan penyesuaian diri mahasiswa dalam perkuliahan. Jurnal Psikologi Persona, 1(1), 40-52.

Qonitatin, N., Widyawati, S., \& Asih, G. Y. (2011). Pengaruh katarsis dalam menulis ekspresif sebagai intervensi depresi ringan pada mahasiswa. Jurnal Psikologi, 9(1), 21-30.

Rahmi, N. (2013). Hubungan tingkat stres dengan prestasi belajar mahasiswa tingkat II prodi D-III kebidanan Banda Aceh Jurusan Kebidanan Poltekkes Kemenkes NAD TA. 2011/2012. Jurnal Ilmiah STIKes U'Budiyah, 2(1), 66-76.

Ramadhanti, D. ., Agustin, M., \& Rachmawati, Y. (2021). Hubungan antara kelekatan pada ayah dengan kecerdasan emosional anak 
usia dini. Jurnal Pertumbuhan, Perkembangan Dan Pendidikan Anak Usia Dini, 18(1), 54-62. https://doi.org/ https://doi.org/10.17509/ edukids.v18i1.24295

Ryff, C. D. (1989). Happiness is everything, or is it? Explorations on the meaning of psychological well-being. Journal of Personality and Social Psychology, 57(6), 1069-1081.

Ryff, Carol D. (1989). Happiness is everything, or is it? Explorations on the meaning of psychological well-being. Journal of Personality and Social Psychology, 57(6), 1069-1081. https:/ / do i org / $10.1037 / 0022$ 3514.57.6.1069

Ryff, Carol D., \& Keyes, C. L. M. (1995). The structure of psychological well-being revisited. Journal of Personality and Social Psychology, 69(4), 719-727. https: / / doi.org/10.1037/00223514.69.4.719

Senduk, R. (2016). Perilaku mahasiswi dalam dunia gemerlap (dugem) di Kota Manado. Jurnal Holistik, 1-20. https://doi.org/10. 1037/0022-3514.54.6.1063

Sibuea, R. . (2019). Hubungan antara kesejahteraan psikologis dengan kontrol diri pada anggota paskibra SMA Kemala
Bhayangkari 1 Medan. Universitas Medan Area/: Medan.

Tangney, J. ., Baumeister, R. ., \& Boone, A. . (2004). High self-control predicts good adjustment, less pathology, better grades , and interpersonal success. Journal of Personality, 72(2), 271-322.

Taufik, N., Nurfarhanah, \& Rahayu, N. (2013). Hubungan antara intimasi dalam keluarga dengan tingkah laku agresif pada siswa. Jurnal Ilmiah Konseling, 2(1), 197-210.

Utami, R. S. (2015). Hubungan antara keterlibatan ayah dalam pengasuhan dengan psychological well-being pada masa dewasa muda anak perempuan.

Watson, D., Clar k, L. A., \& Tellegen, A. (1988). Development and validation of brief measures of positive and negative affect: The PANAS scales. Journal of Personality and Social Development, 54, 1063-1070.

Wulandari, S. (2016). Hubungan antara kesejahteraan psikologis dengan penyesuaian diri siswa kelas X SMK Santa Maria Jakarta. Jurnal Psiko-Edukasi, 14(2), 94-100.

Received 8 February 2021

Revised 26 June 2021

Accepted 31 July 2021 